\title{
Association Between Maternal Vitamin D Status and Risk of Gestational Diabetes Mellitus in Pregnant Women
}

\author{
Gebelerde Ölçülen D Vitamini Seviyeleri ile Gestasyonel Diabetes Mellitus Riski \\ Arasındaki ilişki
}

\author{
Seda Ateş, Serdar Aydın, Ayşe Filiz Gökmen Karasu, Banu Dane \\ Bezmialem Vakıf University Faculty of Medicine, Department of Obstetrics and Gynecology, Istanbul, Turkey
}

\section{Abstract}

Aim: To investigate whether maternal serum levels of 25-hydroxyvitamin $\mathrm{D}[25(\mathrm{OH}) \mathrm{D}]$ in the first trimester is associated with an increased risk of gestational diabetes mellitus (GDM).

Methods: We conducted a cross-sectional study of a cohort of pregnant women who had undergone routine genetic multiple marker screening and subsequent glucose tolerance testing. Twenty-five women with GDM and 208 controls without GDM were included in this study. Plasma 25(OH)D concentrations were measured using liquid chromatography-tandem mass spectrometry.

Results: Mean 25(OH)D concentrations at 11-14 weeks of gestation were not significantly different in women who subsequently developed GDM compared with those who did not (mean \pm standard deviation: 13.969 .05 versus $13.43 \pm 9.72 ; p=0.8)$. The prevalence of first-trimester severe $25(\mathrm{OH}) \mathrm{D}$ deficiency $(<10 \mathrm{ng} / \mathrm{mL})$ was similar between women with GDM and healthy controls ( $44 \%$ vs. $44.7 \%$, respectively; $p=0.9$ ). The mean concentration of 25(OH)D slightly increased over the two gestational age windows both in women with GDM [mean $\Delta 25(\mathrm{OH}) \mathrm{D}$ : $0.25 \pm 5.8 \mathrm{ng} / \mathrm{mL}$ ] and controls [mean $\Delta 25(\mathrm{OH}) \mathrm{D}: 0.84 \pm 12.84 \mathrm{ng} / \mathrm{mL}$ ], but the difference was not statistically significant $(p=0.8)$.

Conclusion: Vitamin D deficiency in early pregnancy is not significantly associated with elevated risk of GDM.

Keywords: Severe vitamin D deficiency, gestational diabetes mellitus, pregnancy
Öz

Amaç: Birinci trimesterde ölçülen maternal 25-hidroksi D [25(OH)D] vitamini serum düzeylerinin gestasyonel diabetes mellitus (GDM) ile ilişkisinin araştırıması.

Yöntemler: Bu kesitsel kohort çalışmayı birinci trimesterde rutin genetik tarama testi yapılan ve sonrasında glukoz tolerans testi uygulanan gebeler üzerinde yaptık. Gestasyonel diyabet tanısı alan 25 gebe ve gestasyonel diyabet tanısı almayan 208 gebe çalışmaya dahil edildi. Plazma 25(OH)D konsantrasyonları, sIVı kromatografisi-tandem kütle spektrometresi yöntemiyle ölçüldü.

Bulgular: GDM gelişen gebelerin ve kontrol grubunun 11-14.gebelik haftalarında ölçülen ortalama 25(OH)D vitamini konsantrasyonları arasında anlamlı fark yoktu (sırasıyla ortalama \pm standart deviasyon: $13,96 \pm 9,05$ vs $13,43 \pm 9,72, p=0,8)$. Ortalama $25(\mathrm{OH}) \mathrm{D}$ konsantrasyonları, hem gestasyonel diyabetli gebelerde hem de kontrol grubunda iki ayrı gebelik haftası aralığında (11-14 gebelik haftası ve 24-28 gebelik haftası) hafifçe artmıştı [ortalama $\Delta 25(\mathrm{OH}) \mathrm{D}$ : 0,25 $\pm 5,8$ $\mathrm{ng} / \mathrm{mL}$ ve ortalama $\Delta 25(\mathrm{OH}) \mathrm{D}$ : $0,84 \pm 12,84 \mathrm{ng} / \mathrm{mL}$; ancak bu fark istatistiksel olarak anlamlı değildi $(p=0,8)$.

Sonuç: Erken gebelik haftasında saptanan 25(OH)D vitamin eksikliği, GDM riski ile ilişkili değildir.

Anahtar Sözcükler: Ciddi D vitamin eksikliği, gestasyonel diabetes mellitus, gebelik

\section{Introduction}

High prevalence of vitamin D deficiency has been established among pregnant women in several countries (1). The estimated prevalence ranges from $3 \%$ to $24 \%$ depending on the country of residence, clothing style, dietary intake, skin pigmentation, sunshine exposure, usage of prenatal vitamins, and definition of vitamin $D$ deficiency (2). Vitamin $D$ is mainly derived from skin photosynthesis and minor proportion is obtained from digestive absorption. Vitamin $\mathrm{D}$ is transformed and metabolized to 25-hydroxyvitamin D [25(OH)D] which is the best determinant of patient's vitamin $D$ status in
Address for Correspondence/Yazışma Adresi: Seda Ateş

Bezmialem Vakıf University Faculty of Medicine, Department of Obstetrics and Gynecology, İstanbul, Turkey Phone: +90 5053929274 E-mail: drsedaates@yahoo.com

Received/Geliş Tarihi: 07 March 2016 Accepted/Kabul Tarihi: 21 April 2016
${ }^{\circ}$ Copyright 2017 by The Medical Bulletin of Haseki Training and Research Hospital The Medical Bulletin of Haseki published by Galenos Yayınevi. ๑Telif Hakkı 2017 Haseki Eğitim ve Araştırma Hastanesi Haseki Tıp Bülteni, Galenos Yayınevi tarafından basılmışır. 
the liver, then, 25(OH)D is metabolized to its active form, $\left[1.25(\mathrm{OH}) \mathrm{D}_{2}\right]$ in the kidneys (3).

Vitamin $D$ is proposed to play an important role in release and maintenance of glucose tolerance, and in insulin synthesis (4). It is well established that pancreatic b-cells express vitamin D receptor (5). Several studies also support that vitamin $D$ deficiency reduces insulin secretion and $1.25(\mathrm{OH}) \mathrm{D}_{2}$ administration improves b-cell function and glucose tolerance $(6,7)$. Vitamin $D$ deficiency predisposes to the development of both type 1 and 2 diabetes $(8,9)$. However, the association of vitamin $D$ deficiency with gestational diabetes mellitus (GDM) is not well established and remains controversial. There is an increasing interest in the relationship between vitamin $D$ status and GDM. Some studies suggested an association between GDM and lower levels of 25(OH)D in pregnant women $(10,11)$, but others reported no significant difference from normoglycaemic controls $(12,13)$.

The present study aimed to examine whether there is an association between maternal vitamin D status in early trimester and the risk of developing GDM. We conducted a secondary analysis to compare the $25(\mathrm{OH}) \mathrm{D}$ levels in the first and second trimesters.

\section{Methods}

We conducted a cross-sectional study of a cohort of pregnant women who attended Bezmialem Vakıf University Faculty of Medicine in İstanbul for routine genetic multiple marker screening between 11 and 14 weeks' gestation between December 2012 and July 2014. All the subjects subsequently had a screening test for gestational diabetes at our hospital during the same pregnancy.

We measured maternal serum levels of $25(\mathrm{OH}) \mathrm{D}$ in 233 consecutive pregnant women in the first trimester after informing about the research. In this visit, we recorded maternal characteristics, medical history and information about the factors associated with vitamin D status. Serum 25(OH)D was also measured in followup samples collected at 24-28 weeks of gestation in a subset of 152 participants. All participants gave informed consent for participation in the study, which was approved by the Ethics Committee of Bezmialem Vakıf University, (71306642/050-01-04/553).

Data on maternal characteristics included age, parity, blood pressure, pre-pregnancy weight, height, date of the last menstrual period, education level, gestational age at blood sampling, type of clothing, use of multivitamin supplements, and season of blood collection. Gestational age was calculated according to the last menstrual period and ultrasound estimates of gestational age were used in cases of uncertain menstrual dates. Covered dressing style was defined as wearing dresses which cover body completely excluding hands and face whereas uncovered dressing style was wearing dresses exposing body to more sun light in a permissive manner. The season for blood collection was dichotomized into winter months (November-April) and summer months (May-October). Maternal body mass index (BMI) was calculated from the patient's self-reported height and pre-pregnancy weight. Education was categorized as low ( $\leq 5$ years of education), mid (6-10 years), and high ( $\geq 9$ years).

Women with known or clinically suspected pregestational diabetes, pregestational hypertension, history of thyroid, parathyroid or adrenal disease, hepatic or renal failure, metabolic bone disease and those taking medications that might affect vitamin D metabolism were excluded from the study. Multiple pregnancies were also excluded. None of the women in this study had previously received vitamin $D$ or calcium supplementation.

In this study, the cases were defined as women who met the diagnostic criteria for GDM. The diagnosis of GDM was based on using a two-step approach. Initial screening for GDM was performed between 24 and 28 weeks of gestation using a 1-hour 50-gram glucose challenge test. Patients with a blood glucose level of $>185 \mathrm{mg} / \mathrm{dL}$ at the first hour were considered to have GDM and, if the concentration was more than $140 \mathrm{mg} / \mathrm{dL}$, an oral glucose tolerance test (OGTT) using a 100-g oral glucose load was carried out within the subsequent 2 weeks. GDM was diagnosed if at least two plasma glucose levels were above the following cut-offs, including fasting plasma glucose $\geq 95 \mathrm{mg} / \mathrm{dL}$, plasma glucose one hour after OGTT $\geq 180 \mathrm{mg} / \mathrm{dL}$, plasma glucose two hours after OGTT $\geq 155$ $\mathrm{mg} / \mathrm{dL}$ and plasma glucose three hours after OGTT $\geq 140$ $\mathrm{mg} / \mathrm{dL}$ (14). Women with a diagnostically negative $50-\mathrm{g}$ glucose challenge test were eligible to serve as controls.

Measurement of $25(\mathrm{OH}) \mathrm{D}_{3}$ and $25(\mathrm{OH}) \mathrm{D}_{2}$ in human serum was made by using liquid chromatography-tandem mass spectrometry (LC-MS/MS) with an Agilent 1200 Infinity LC (Agilent Technologies) coupled to an Agilent Technologies 6460 LC-MS/MS. The summation of serum $25(\mathrm{OH}) \mathrm{D}_{2}$ and $25(\mathrm{OH}) \mathrm{D}_{3}$ was used to reflect total serum 25(OH)D concentrations. The inter-assay and intra-assay coefficients of variation of total serum $25(\mathrm{OH}) \mathrm{D}$ level were $6.84 \%$ and $2.21 \%$, respectively. The lower and upper limits of detection were 4.0 and $200 \mathrm{ng} / \mathrm{mL}$, respectively. Values that were outside the limits of detection were excluded from the analysis. We used the cutoff point of $10 \mathrm{ng} / \mathrm{mL}$ which has been suggested by some experts to define severe vitamin $D$ deficiency (15). Depending on their 25(OH)D levels, the women were categorized into two groups. Values of $25(\mathrm{OH}) \mathrm{D}<10 \mathrm{ng} / \mathrm{mL}$ were included in group 1 and the values $\geq 10 \mathrm{ng} / \mathrm{mL}$ were included in group 2. 


\section{Statistical Analysis}

Data were expressed as mean \pm standard deviation or number and percentage as appropriate and a $p$ value of less than 0.05 was considered statistically significant. Statistical analysis was performed after normality testing (histogram analysis and/or Kolmogorov-Smirnov) using IBM SPSS version 21. Student's t-test was used for comparisons of normally distributed variables, the MannWhitney $U$ test for non-normally distributed variables. Chisquare and Fisher's exact tests were used to compare the proportion of categorical variables.

\section{Results}

A total of 286 women (11-14 weeks of pregnancy) were recruited during the study period. 53 of them were excluded from the analysis. Reasons for exclusion were deciding to be followed-up elsewhere $(n=15)$, being lostto-follow up ( $n=27)$, insufficient serum available for analysis $(n=8)$, miscarriage $(n=2)$ and termination of pregnancy because of Down syndrome $(n=1)$. After exclusion of the women mentioned above, 233 women were available to be included in the analysis. Of the 233 participants, we consecutively enrolled 25 pregnant women with GDM as the study group and 208 women without GDM as the control group.

The demographic and clinical characteristics of pregnant women with GDM and controls are given in Table 1. The mean maternal age was $30.7 \pm 4.5$ years in women with GDM and $29.1 \pm 5$ in nondiabetic controls. The mean BMI in women with GDM and controls was $27.33 \pm 6.05$ and $25.29 \pm 5.47 \mathrm{~kg} / \mathrm{m}^{2}$, respectively $(p=0.09)$. There were no differences between the two groups concerning age, BMI, parity, education level, dressing style, use of multivitamin supplements or the season when blood sample was drawn. The median serum 25(OH)D concentration was $13.96 \pm 9.05 \mathrm{ng} / \mathrm{mL}$ in women with GDM and $13.43 \pm 9.72$ $\mathrm{ng} / \mathrm{mL}$ in controls at 11-14 weeks of gestation. Maternal $25(\mathrm{OH}) \mathrm{D}$ concentrations in women who developed GDM were similar to those in controls at the first trimester. Women who subsequently developed GDM had a higher diastolic blood pressure at the 11-14 weeks of gestation compared to controls $(p=0.03)$, however, the systolic blood pressures in the GDM group were not significantly different from controls.

The prevalence of severe first-trimester maternal $25(\mathrm{OH}) \mathrm{D}$ deficiency $(<10 \mathrm{ng} / \mathrm{mL})$ was similar between women with GDM and healthy controls (44\% vs. $44.7 \%$, respectively; $p=0.9$ ). In a subset of 152 women, the $25(\mathrm{OH})$ $D$ levels were also determined during the second trimester. The prevalence of severe 25(OH)D deficiency $(<10 \mathrm{ng} /$ $\mathrm{mL}$ ) at 24-28 weeks of gestation was $33.3 \%$ in women with GDM and $46.7 \%$ in nondiabetic controls $(p=0.3)$. The mean 25(OH)D concentration slightly increased over the two gestational age windows both in women with GDM

\begin{tabular}{|c|c|c|c|}
\hline & $\begin{array}{l}\text { Women with gestational } \\
\text { diabetes }(n=25)\end{array}$ & $\begin{array}{l}\text { Control subjects } \\
(n=208)\end{array}$ & $\mathbf{p}$ \\
\hline Maternal age (years) & $30.7 \pm 4.5$ & $29.1 \pm 5$ & 0.1 \\
\hline $\mathrm{BMI}\left(\mathrm{kg} / \mathrm{m}^{2}\right)$ & $27.33 \pm 6.05$ & $25.29 \pm 5.47$ & 0.09 \\
\hline Parity & $1.83 \pm 0.5$ & $1.65 \pm 0.5$ & 0.1 \\
\hline $\begin{array}{l}\text { Education, } \mathbf{n}(\%) \\
\text { 0-5 years } \\
\text { 6-8 years } \\
\geq 9 \text { years }\end{array}$ & $\begin{array}{l}11(44) \\
5(20) \\
9(36)\end{array}$ & $\begin{array}{l}69(33.2) \\
42(20.2) \\
97(66.6)\end{array}$ & 0.5 \\
\hline Mean systolic BP at trial entry $(\mathrm{mmHg})$ & $105.4 \pm 9.3$ & $103.3 \pm 11$ & 0.3 \\
\hline Mean diastolic BP at trial entry $(\mathrm{mmHg})$ & $70.4 \pm 8.1$ & $66.5 \pm 8.5$ & 0.03 \\
\hline Use of multivitamin, $\mathrm{n}(\%)$ & $9(36)$ & $87(41.8)$ & 0.1 \\
\hline $\begin{array}{l}\text { Dressing style, } \mathbf{n}(\%) \\
\text { Covered } \\
\text { Uncovered }\end{array}$ & $\begin{array}{l}12(48) \\
13(52)\end{array}$ & $\begin{array}{l}109(52.4) \\
99(47.6)\end{array}$ & 0.7 \\
\hline $25(\mathrm{OH}) \mathrm{D}$ concentration $(\mathrm{ng} / \mathrm{mL})$ measured at $11-14$ weeks of gestation (visit 1) & $13.96 \pm 9.05$ & $13.43 \pm 9.72$ & 0.8 \\
\hline $25(\mathrm{OH}) \mathrm{D}$ concentration $(\mathrm{ng} / \mathrm{mL})$ measured at $24-28$ weeks of gestation (visit 2) & $14.99 \pm 10.2(n=15)$ & $14.43 \pm 10.96(n=137)$ & 0.8 \\
\hline $\begin{array}{l}\text { Season of blood draw (visit 1), n (\%) } \\
\text { Winter (November-April) } \\
\text { Summer (May-October) }\end{array}$ & $\begin{array}{l}12(48) \\
13(52)\end{array}$ & $\begin{array}{l}99(47.6) \\
109(52.4)\end{array}$ & 0.9 \\
\hline $\begin{array}{l}\text { Season of blood draw (visit 2), n (\%) } \\
\text { Winter (November-April) } \\
\text { Summer (May-October) }\end{array}$ & $\begin{array}{l}8(56.3) \\
7(43.7)\end{array}$ & $\begin{array}{l}77(56.2) \\
60(43.8)\end{array}$ & 0.6 \\
\hline
\end{tabular}


(mean $\Delta 25(\mathrm{OH}) \mathrm{D}=0.25 \pm 5.8 \mathrm{ng} / \mathrm{mL}$ ) and normal pregnant women (mean $\Delta 25(\mathrm{OH}) \mathrm{D}=0.84 \pm 12.84 \mathrm{ng} / \mathrm{mL}$ ), whereas the difference was not statistically significant $(p=0.8)$ (Table 2).

The serum concentrations of $25(\mathrm{OH}) \mathrm{D}$ in women with GDM and controls are presented in Table 3. The firsttrimester 25(OH)D concentrations in women whose blood samples were drawn during the winter (November-April) were significantly lower than those in women whose first trimester occurred during the summer (May-October) $(p<0.0001)$ while, no significant difference was observed in mean serum $25(\mathrm{OH}) \mathrm{D}$ concentration in the second trimester both in summer and winter season $(p=0.3)$.

\section{Discussion}

The main finding of our study is the lack of significant difference in maternal vitamin $D$ levels between pregnant women who develop GDM and normoglycemic controls. The association between GDM and vitamin D deficiency is controversial. Savvidou et al. (16) investigated maternal serum $25(\mathrm{OH}) \mathrm{D}$ levels at $11^{+0}-13^{+6}$ weeks of gestation in three groups of complicated pregnancies including women who had type 2 diabetes, women who subsequently developed GDM and nondiabetic women who delivered macrosomic neonates, and they failed to find a significant difference in vitamin D levels compared to those in nondiabetic controls. Similarly, Makgoba et al. (17) examined first-trimester maternal serum $25(\mathrm{OH})$ $D$ levels and GDM in a case-control study of 90 pregnant women and did not find an evidence of an association in women with GDM compared to 158 controls. In another study, Farrant et al. (13) measured maternal serum 25(OH) D concentrations at 30 weeks of gestation in 559 women and did not find an association between maternal 25(OH)D deficiency and the risk of GDM. Another case-control study found no association between maternal serum 25(OH)D levels (measured between 11 and 14 weeks of pregnancy) and the development of GDM among pregnant women, which is consistent with our results (18).

On the other hand, there are several studies which reported a significant association between vitamin $D$ deficiency and GDM. Recently, Zuhur et al. (19) studied 234 cases of GDM and 168 controls in Turkey and reported that only severely deficient maternal serum $25(\mathrm{OH}) \mathrm{D}$ levels $(<5.2 \mathrm{ng} / \mathrm{mL}$ ) were significantly associated with an elevated relative risk of GDM. Likewise, Maghbooli et al. (11) studied maternal vitamin $\mathrm{D}$ deficiency and GDM in a cross-sectional study of 741 pregnant women at 24-28-weeks gestation and found significantly lower levels of 25(OH)D in women with GDM compared to normoglycaemic controls. They reported higher rate of severe vitamin $D$ deficiency $(<10$ $\mathrm{ng} / \mathrm{mL})(70.6 \%)$ compared to that in our study (44.6\%) and suggested that severe vitamin $D$ deficiency might contribute to insulin resistance. In a large cohort study, Zhang et al. (20) studied vitamin D deficiency in early pregnancy (mean gestational age: 16 weeks) and found a 2.66-fold increased risk of GDM in women with vitamin $D$ deficiency. The prevalence of vitamin $D$ deficiency $(<20$ $\mathrm{ng} / \mathrm{mL}$ ) was found to be high in $20 \%$ of women in this cohort. Previous studies have reported conflicting results about the association between vitamin $\mathrm{D}$ deficiency and GDM which may be explained by the methodological issues, such as sample size, study design, gestational age at sampling (early or late gestation), and the method used to measure vitamin D. Additionally, some other factors, such as criteria of GDM, definition of vitamin D deficiency, ethnic and genetic characteristics of the participants might contribute to inconsistent findings between the studies.

There are several studies reporting high prevalence of vitamin $\mathrm{D}$ deficiency among pregnant women and

\begin{tabular}{|l|l|l|l|}
\hline \multicolumn{2}{|l|}{ Table 2. Maternal severe vitamin D deficiency at 11-14 and 24-28 weeks of gestation } \\
\hline & Women with gestational diabetes & Control subjects & p \\
\hline $\begin{array}{l}\text { Severe vitamin } \mathrm{D} \text { deficiency }[25(\mathrm{OH}) \mathrm{D} \text { level }<10 \mathrm{ng} / \mathrm{mL}] \text { measured at 11-14 } \\
\text { weeks of gestation (visit 1), } \mathrm{n}(\%)\end{array}$ & $11(44 \%)$ & $93(44.7 \%)$ \\
\hline $\begin{array}{l}\text { Severe vitamin D deficiency }(25(\mathrm{OH}) \mathrm{D} \text { level }<10 \mathrm{ng} / \mathrm{mL}) \text { measured at } 24-28 \\
\text { weeks of gestation (visit 2), } \mathrm{n}(\%)\end{array}$ & $5(33.3 \%)$ & $63(46.7)$ & 0.9 \\
\hline$\Delta 25(\mathrm{OH}) \mathrm{D}(\mathrm{V} 2-\mathrm{V} 1)$ & $0.25 \pm 5.8$ & $0.84 \pm 12.84$ \\
\hline Data are shown as mean \pm standard deviation, median (minimum-maximum) or $\mathrm{n}(\%), 25(\mathrm{OH}) \mathrm{D}: 25$-hydroxyvitamin $\mathrm{D}$ & 0.8 \\
\hline
\end{tabular}

Table 3. Seasonal variations of serum 25-hydroxyvitamin D concentrations

\begin{tabular}{|l|l|l|l|}
\hline & Summer season (May-October) & Winter season (November-April) & p \\
\hline $\begin{array}{l}\text { 25(OH)D concentration }(\mathrm{ng} / \mathrm{mL}) \text { measured at 11-14 weeks } \\
\text { of gestation (visit 1) }\end{array}$ & $16.48 \pm 11.02$ & $10.2 \pm 6.43$ & $<0.0001$ \\
\hline $\begin{array}{l}\text { 25(OH)D concentration }(\mathrm{ng} / \mathrm{mL}) \text { measured at 24-28 weeks } \\
\text { of gestation (visit 2) }\end{array}$ & $15.5 \pm 9.61$ & $13.74 \pm 11.79$ & 0.3 \\
\hline Data are shown as mean \pm standard deviation, 25(OH)D: 25-hydroxyvitamin D & & \\
\hline
\end{tabular}


advocating the need for pharmacological intervention as low maternal vitamin $D$ status was thought to be related to the increased risk of adverse pregnancy outcomes $(21,22)$.

The 25(OH)D levels showed a moderate, but statistically non-significant increase towards the first to the second trimester in the present study. This is in contrast with the findings of the study by Fernández-Alonso et al. (23) who reported a decline in serum 25(OH)D concentration with progression of pregnancy. In agreement with our findings, Marwaha et al. (24) have shown no change in $25(\mathrm{OH})$ $D$ concentrations with progression of pregnancy which could partly be explained by the food products that are not fortified with vitamin $D$ and the absence of current guidelines on recommending mandatory vitamin $D$ supplementation during pregnancy. In a study by Zhao et al. (25), the mean level of 25(OH)D in the second trimester was significantly higher than the one in the first trimester and equivalent to the one in the third trimester. Our results are compatible with the recent study which reported high prevalence of severe vitamin $D$ deficiency $[25(\mathrm{OH})$ $\mathrm{D}<10 \mathrm{ng} / \mathrm{mL}$ ] (45.6\%) among pregnant women in Turkey (26). These findings indicate that vitamin $D$ deficiency is a major health problem in our population as well. A previous study demonstrated that ethnic differences in serum $25(\mathrm{OH}) \mathrm{D}$ levels were the primary determinant of increased risk of diabetes (27). Decreasing the risk of GDM in pregnancy may have a beneficial effect in reducing the number of adverse perinatal complications, including fetal macrosomia, prematurity, hypoglycaemia, birth trauma, hyperbilirubinemia and Caesarean section that have been linked to GDM (28).

Strengths of the current study include its prospective design and the use of the gold standard method for measuring $25(\mathrm{OH}) \mathrm{D}$ levels. One of the limitations of our study was its relatively small sample size and the small number of women with GDM compared with other studies. Secondly, we only measured 25(OH)D levels at two time points in pregnancy with the second time point including a significantly smaller number of participants.

\section{Conclusion}

In conclusion, our study demonstrated that vitamin D deficiency in early pregnancy is not significantly associated with elevated risk for GDM. Further well-designed, large and prospective cohort studies are required to explore the effects of vitamin D deficiency on GDM and the dose of vitamin $D$ supplementation that ensures adequate vitamin D status in pregnancy.

\section{Ethics}

Ethics Committee Approval: Bezmialem Vakif University, 71306642/050-01-04/553. Informed Consent:
All participants gave informed consent for participation in the study.

Peer-review: Internally peer-reviewed.

\section{Authorship Contributions}

Surgical and Medical Practices: Seda Ateş, Serdar Aydın. Concept: Seda Ateş, Banu Dane. Design: Seda Ateş, Serdar Aydın. Data Collection or Processing: Seda Ateş, Serdar Aydın. Analysis or Interpretation: Serdar Aydın. Literature Search: Seda Ateş, Ayşe Filiz Gökmen Karasu. Writing: Seda Ateş.

Conflict of Interest: The authors report no declarations of interest.

Financial Disclosure: The authors declared that this study received no financial support.

\section{References}

1. Kimball S, Fuleihan Gel-H, Vieth R. Vitamin D: a growing perspective. Crit Rev Clin Lab Sci 2008;45:339-414.

2. Mulligan $M L$, Felton $S K$, Riek $A E$, Bernal-Mizrachi $C$. Implications of vitamin D deficiency in pregnancy and lactation. Am J Obstet Gynecol 2010;202:429.

3. Holick MF. Vitamin D deficiency. N Engl J Med 2007;357:26681.

4. Teegarden D, Donkin SS. Vitamin D: emerging new roles in insulin sensitivity. Nutr Res Rev 2009;22:82-92.

5. Lee S, Clark SA, Gill RK, Christakos S. 1,25-Dihydroxyvitamin D3 and pancreatic beta-cell function: vitamin D receptors, gene expression, and insulin secretion. Endocrinology 1994;134:1602-10.

6. Ye WZ, Reis AF, Dubois-Laforgue $D$, et al. Vitamin D receptor gene polymorphisms are associated with obesity in type 2 diabetic subjects with early age of onset. Eur J Endocrinol 2001;145:181-6.

7. Norman AW, Frankel JB, Heldt AM, Grodsky GM. Vitamin $D$ deficiency inhibits pancreatic secretion of insulin. Science 1980;209:823-5.

8. Mathieu C, Badenhoop K. Vitamin D and type 1 diabetes mellitus: state of the art. Trends Endocrinol Metab 2005;16:261-6.

9. Pittas AG, Lau J, Hu FB, Dawson-Hughes B. The role of vitamin $\mathrm{D}$ and calcium in type 2 diabetes. A systematic review and meta-analysis. J Clin Endocrinol Metab 2007;92:2017-29.

10. Soheilykhah S, Mojibian M, Rashidi M, Rahimi-Saghand S, Jafari F. Maternal vitamin D status in gestational diabetes mellitus. Nutr Clin Pract 2010;25:524-7.

11. Maghbooli Z, Hossein-Nezhad A, Karimi F, Shafaei AR, Larijani B. Correlation between vitamin D3 deficiency and insulin resistance in pregnancy. Diabetes Metab Res Rev 2008;24:27-32.

12. Clifton-Bligh RJ, McElduff P, McElduff A. Maternal vitamin D deficiency, ethnicity and gestational diabetes. Diabet Med 2008;25:678-84.

13. Farrant HJ, Krishnaveni GV, Hill JC, et al. Vitamin D insufficiency is common in Indian mothers but is not associated with 
gestational diabetes or variation in newborn size. Eur J Clin Nutr 2009;63:646-52.

14. No authors listed. Classification and diagnosis of diabetes mellitus and other categories of glucose intolerance. National Diabetes Data Group. Diabetes 1979;28:1039-57.

15. Holick MF, Siris ES, Binkley N, et al. Prevalence of Vitamin D inadequacy among postmenopausal North American women receiving osteoporosis therapy. J Clin Endocrinol Metab 2005;90:3215-24.

16. Savvidou MD, Akolekar R, Samaha RB, Masconi AP, Nicolaides $\mathrm{KH}$. Maternal serum 25-hydroxyvitamin D levels at 11(+0) $-13(+6)$ weeks in pregnant women with diabetes mellitus and in those with macrosomic neonates. BJOG 2011;118:951-5.

17. Makgoba M, Nelson SM, Savvidou M, Messow CM, Nicolaides K, Sattar N. First-trimester circulating 25-hydroxyvitamin D levels and development of gestational diabetes mellitus. Diabetes Care 2011;34:1091-3.

18. Baker AM, Haeri S, Camargo CA Jr, Stuebe AM, Boggess $K A$. First-trimester maternal vitamin $D$ status and risk for gestational diabetes (GDM) a nested case-control study. Diabetes Metab Res Rev 2012;28:164-8.

19. Zuhur SS, Erol RS, Kuzu I, Altuntas Y. The relationship between low maternal serum 25-hydroxyvitamin D levels and gestational diabetes mellitus according to the severity of 25-hydroxyvitamin D deficiency. Clinics (Sao Paulo) 2013;68:658-64.

20. Zhang C, Qiu C, Hu FB, et al. Maternal plasma 25-hydroxyvitamin D concentrations and the risk for gestational diabetes mellitus. PLoS One 2008;3:3753.
21. Johnson DD, Wagner CL, Hulsey TC, McNeil RB, Ebeling M, Hollis BW. Vitamin D deficiency and insufficiency is common during pregnancy. Am J Perinatol 2011;28:7-12.

22. Barrett $H$, McElduff A. Vitamin D and pregnancy: An old problem revisited. Best Pract Res Clin Endocrinol Metab 2010;24:527-39.

23. Fernández-Alonso AM, Dionis-Sánchez EC, Chedraui $P$, González-Salmerón MD, Pérez-López FR; Spanish Vitamin D and Women's Health Research Group. First-trimester maternal serum 25-hydroxyvitamin $D_{3}$ status and pregnancy outcome. Int J Gynaecol Obstet 2012;116:6-9.

24. Marwaha RK, Tandon N, Chopra S, et al. Vitamin D status in pregnant Indian women across trimesters and different seasons and its correlation with neonatal serum 25-hydroxyvitamin D levels. Br J Nutr 2011;106:1383-9.

25. Zhao Y, Miao W, Li C, et al. Dynamic changes in serum 25-hydroxyvitamin D during pregnancy and lack of effect on thyroid parameters. PLoS One 2014;9:90161.

26. Ustuner I, Keskin HL, Tas EE, Neselioglu S, Sengul O, Avsar AF. Maternal serum 25(OH)D levels in the third trimester of pregnancy during the winter season. J Matern Fetal Neonatal Med 2011;24:1421-6.

27. Scragg R, Sowers M, Bell C; Third National Health and Nutrition Examination Survey. Serum 25-hydroxyvitamin D, diabetes, and ethnicity in the Third National Health and Nutrition Examination Survey. Diabetes Care 2004;27:2813-8.

28. Mitanchez D. Foetal and neonatal complications in gestational diabetes: perinatal mortality, congenital malformations, macrosomia, shoulder dystocia, birth injuries, neonatal complications. Diabetes Metab 2010;36:617-27. 